\title{
Inhibition of hepatitis $C$ virus by an M1GS ribozyme derived from the catalytic RNA subunit of Escherichia coli RNase P
}

Xinliang $\mathrm{Mao}^{1}$, Xifang $\mathrm{Li}^{2}$, Xinjun Mao ${ }^{3}$, Zhiwen Huang ${ }^{2}$, Chengcheng Zhang ${ }^{2}$, Wenjun Zhang ${ }^{2,4^{*}}$, Jianguo Wu ${ }^{4}$ and Gang $\mathrm{Li}^{1 *}$

\begin{abstract}
Background: Hepatitis C virus (HCV) is a human pathogen causing chronic liver disease in about 200 million people worldwide. However, HCV resistance to interferon treatment is one of the important clinical implications, suggesting the necessity to seek new therapies. It has already been shown that some forms of the catalytic RNA moiety from E. coli RNase P, M1 RNA, can be introduced into the cytoplasm of mammalian cells for the purpose of carrying out targeted cleavage of mRNA molecules. Our study is to use an engineering M1 RNA (i.e. M1GS) for inhibiting HCV replication and demonstrates the utility of this ribozyme for antiviral applications.
\end{abstract}

Results: By analyzing the sequence and structure of the $5^{\prime}$ untranslated region of HCV RNA, a putative cleavage site $\left(C^{67}-G^{68}\right)$ was selected for ribozyme designing. Based on the flanking sequence of this site, a targeting M1GS ribozyme (M1GS-HCV/C 67 ) was constructed by linking a custom guide sequence (GS) to the 3 ' termini of catalytic RNA subunit (M1 RNA) of RNase P from Escherichia coli through an $88 \mathrm{nt}$-long bridge sequence. In vitro cleavage assays confirmed that the engineered M1GS ribozyme cleaved the targeted RNA specifically. Moreover, $85 \%$ reduction in the expression levels of HCV proteins and $>1000$-fold reduction in viral growth were observed in supernatant of cultured cells that transfected the functional ribozyme. In contrast, the HCV core expression and viral growth were not significantly affected by a "disabled" ribozyme (i.e. M1GS-HCV/C $67^{*}$ ). Moreover, cholesterol-conjugated M1GS ribozyme (i.e. Chol-M1GS-HCV/C 67 ) showed almost the same bioactivities with M1GS-HCV/C 67 , demonstrating the potential to improve in vivo pharmacokinetic properties of M1GS-based RNA therapeutics.

Conclusion: Our results provide direct evidence that the M1GS ribozyme can function as an antiviral agent and effectively inhibit gene expression and multiplication of HCV.

Keywords: Ribozyme, RNase P, Hepatitis C virus, 5' UTR, Antiviral

\section{Background}

Hepatitis $\mathrm{C}$ virus (HCV), a member of the Flaviviridae family, causes chronic liver disease in about 200 million people worldwide. Its single-stranded RNA genome comprises a $5^{\prime}$ untranslated region (UTR), a long open reading frame and a $3^{\prime}$-noncoding region, and functions as the only mRNA species for translation. The $5^{\prime}$ UTR serves as

\footnotetext{
*Correspondence: zhangwj@gdpu.edu.cn; Ig3195@gmail.com

${ }^{2}$ Department of Microbiology and Immunology, Guangdong Pharmaceutical University, Guangzhou Higher Education Mega Center, Guangzhou 510006, PR China

'Vaccine Institute, The Third Affiliated Hospital of Sun Yat-sen University, Guangzhou 510630, PR China

Full list of author information is available at the end of the article
}

an internal ribosome entry site (IRES), while the open reading frame encodes a polyprotein precursor $(\sim 3010$ amino acids), which is cleaved into structural and nonstructural proteins [1]. HCV is known to cause persistent infection and result in severe liver damages, including cirrhosis, hepatic steatosis and hepatocellular carcinoma [2]. Current clinical approaches are unable to provide satisfactory therapy for $\mathrm{HCV}$-infected patients. For example, the combination of interferon-alpha with ribavirin and/or viral protease inhibitors is effective only in $40 \%$ of infected population [3]. Moreover, the efficacy of treatment usually 
depends on the particular HCV genotype [4]. Therefore, novel antiviral agents and therapies are urgently needed.

Among the proposed antiviral agents are the ribozyme derived from ribonuclease $\mathrm{P}$ (RNase $\mathrm{P}$ ), which is a ribonucleoprotein complex with ribozyme activity that catalyzes a hydrolysis reaction to remove the leader sequence of pre-tRNA and generate mature tRNA [5]. In Escherichia coli, RNase P consists of an RNA subunit (M1 RNA) and a protein subunit (C5 protein). The catalytic M1 RNA can cleave the pre-tRNA substrate in vitro at high divalent ion concentrations in the absence of $\mathrm{C} 5$ protein [6]. Moreover, M1 RNA is able to cleave a target RNA sequence efficiently if an additional small RNA is covalently linked to the 3' end of M1 RNA. The new sequence-specific ribozyme is named M1GS ribozyme (Figure $1 \mathrm{~A}$ ) [7,8], and any RNA could in principle be targeted by a custom-designed M1GS for specific cleavage. When introduced into human cells, M1GS ribozyme can function independently from the endogenous human RNase $\mathrm{P}$ to cleave a targeting sequence that base pairs with the guide sequence [9]. A number of studies have shown that M1GS RNA and RNase $\mathrm{P}$ are effective to cleave both viral and cellular mRNAs and block their expression in cultured cells, including inhibition of gene expression of human influenza, herpes viruses, human cytomegalovirus and human immunodeficiency virus [10-15]. Therefore, M1GS-based strategy is not only a useful method in basic research (e.g. regulation of gene expression) but also represents a distinctive therapeutic approach of nucleic-acid-based, sequence-specific interference [16].

By using RNase P as a tool, the genomic RNA of HCV and the related animal pestiviruses has been previously found to be directly processed in vitro by wild type RNase $\mathrm{P}$ of either human origin or Synechocistis sp but not by the wild type E. coli RNase P ribozyme (M1 RNA) [17-20]. Therefore, we attempt to use the M1GS ribozyme to develop a new anti-HCV strategy and nucleic acid agent. In this study, we chose the 5' UTR of HCV genome as the target region as it is relatively conserved and important for the initiation of viral polyprotein translation [21]. We show here that M1GS ribozyme was able to efficiently cleave the target RNA sequence in vitro. Also about $85 \%$ reduction of $\mathrm{HCV}$ core protein expression and $\geq 1000$-fold reduction of viral growth were observed in cells transfected with the functional M1GS ribozyme.

\section{Materials and methods}

Viruses, cells and antibodies

HCV strain JFH1 (GT2a) was kindly provided by Dr. Takaji Wakita (National Institute of Infectious Disease,

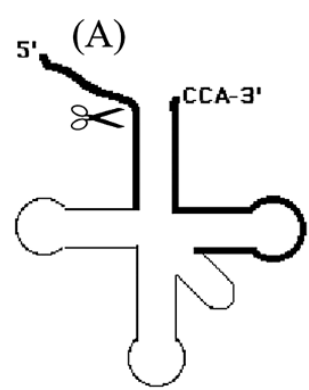

pre-tRNA

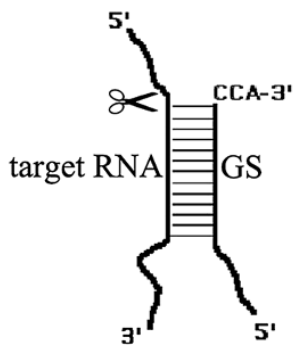

GS:target RNA

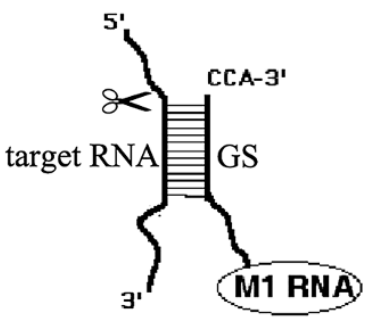

M1GS:target RNA

(B)

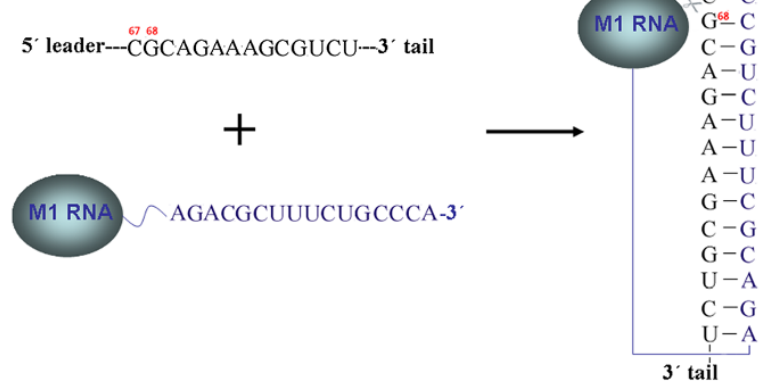

Figure 1 Schematic representation of RNase P substrates. (A) A natural substrate (pre-tRNA), a small model substrate (GS:target RNA) for M1 RNA from E. coli, and a complex structure formed between a M1GS RNA and its RNA substrate. The structural components common to pre-tRNA are highlighted. The site of cleavage by RNase P or M1 RNA is marked with scissors. (B) The substrate and M1GS ribozyme constructed in this study. The targeted sequence and guide sequence of the ribozyme are lettered in black and in blue, respectively. 
Tokyo, Japan). Huh7.5.1 cells were kindly provided by Dr. Francis Chisari (The Scripps Research Institute, California, USA) and were cultured in Dulbecco's modified Eagle's medium (DMEM) supplemented with $10 \%$ fetal calf serum (FCS), $100 \mathrm{U} / \mathrm{ml}$ penicillin and $100 \mu \mathrm{l} / \mathrm{ml}$ streptomycin sulfate. The monoclonal antibody MBS140205, which reacts with HCV core protein, was purchased from MyBioSource, Inc (San Diego, USA). The monoclonal antibody against human GAPDH was purchased from Guangzhou Whiga Technology Co., Ltd (Guangzhou, China).

\section{Ribozyme and substrate constructs}

By analyzing the sequence and structure of the 5' UTR of HCV RNA, a putative cleavage site $\left(C^{67}-G^{68}\right)$ was selected for designing ribozyme. Based on the flanking sequence of this site, a targeting M1GS ribozyme (M1GS-HCV/C 67 ) was constructed by linking a custom guide sequence (GS) to the 3 ' termini of catalytic RNA. Plasmid pFL117, which contains the DNA sequence encoding M1 RNA driven by the T7 RNA polymerase promoter, was a gift from Prof. Fenyong Liu (University of California, Berkeley). The DNA sequences that encode ribozymes M1GS-HCV/C 67 and $\mathrm{M} 1 \mathrm{GS}-\mathrm{HCV} / \mathrm{C}_{67}$ * were constructed by PCR using the DNA sequence of M1 RNA as templates, with oligonucleotides P1 (5' - CGGAATTCGAAGCTGACCAG ACAG-3') as the forward primers, and P2 (5' - CCCA AGCTTGGTGTATAGCCATGGCTGTGGAATTGTG AGCG-3') and P2*(5' - CCCAAGCTTGGTGTATAGC CATGGCAGGTGAAACTGACCGA-3') as the reverse primers, respectively. The two PCR products were further inserted into the multiple cloning site of the vector (pUC19) between the restriction sites EcoR I and Hind III, and two recombinant plasmids containing gene of M1GS ribozyme were constructed, i.e. pM1GS$\mathrm{HCV} / \mathrm{C}_{67}$ and $\mathrm{pM} 1 \mathrm{GS}-\mathrm{HCV} / \mathrm{C}_{67}{ }^{*}$, respectively. The DNA sequence that encodes substrate $\mathrm{S}_{1-584}$ was constructed by PCR using plasmid pGEM-HCJ4 (a gift from Prof. Zhongtian Qi, The Second Military Medical University, China) as template, and oligonucleotides P3 (5'-CGG AATTCGCCAGCCCCCTGATGG-3') and P4 (5'-CG GGATCCGACGCCATCGCCGATGCGGGGCGATCC TATAGTGAG-3') as forward and reverse primers, respectively. The PCR product was then inserted into the multiple cloning site of vector pGEM3z (between restriction sites EcoR I and Hind III), and a recombinant plasmid containing DNA sequence that encodes the substrate $\left(\mathrm{S}_{1-584}\right)$ was constructed, i.e. pGEM-S. Another irrelevant substrate, segment of HCMV UL97 mRNA (1-600 nt), was selected as a control of cleavage assay. The corresponding recombinant plasmid was subcloned in a previous study [22].

\section{In vitro cleavage by M1GS RNA}

The M1GS RNAs and $\mathrm{S}_{1-584}$ RNA substrate were synthesized in vitro with T7 RNA polymerase (Takara
Biotechnology Co., Ltd, Dalian, China) according to the manufacture's recommendations and purified on $8 \%$ urea/polyacrylamide gels. In addition, a cholesterolmodified M1GS RNA (i.e. Chol-M1GS), which conjugated a cholesterol molecule to the $5^{\prime}$ terminus of M1 RNA through a pyrrolidine linker, was synthesized (Guangzhou RiboBio Co., Ltd., China). Subsequently, the M1GS RNAs $(10 \mathrm{nM})$ were mixed with the $\left[{ }^{32} \mathrm{P}\right]$-labeled RNA substrate $(10 \mathrm{nM})$. The cleavage reactions were carried out at $37^{\circ} \mathrm{C}$ in a volume of $10 \mathrm{ul}$ for $30 \mathrm{~min}$ in a buffer consisting of $50 \mathrm{mM}$ Tris ( $\mathrm{pH}$ 7.5), $100 \mathrm{mM} \mathrm{NH}_{4} \mathrm{Cl}$ and $100 \mathrm{mM}$ $\mathrm{MgCl}_{2}$. Reaction was stopped by the addition of $10 \mathrm{ul}$ solution containing $7 \mathrm{~mol} / \mathrm{L}$ urea, $0.05 \%$ bromophenol blue and $0.05 \%$ xylene cyanol. Cleavage products were separated in denaturing gels and quantitated with a Typhoon 9200 phosphorImager (Amersham Biosciences).

\section{M1GS RNA internalization and viral infection}

Huh7.5.1 cells were seeded at a density of $5.0 \times 10^{5}$ cells per well in 6-well plates and grown to approximately $80 \%$ confluence prior to transfection. M1GS RNAs were transfected into cells by using Lipofectamine 2000 reagent (Invitrogen). Lipofectamine 2000 reagent was diluted in $100 \mu \mathrm{l}$ of Opti-MEM medium with the M1GS to give a final concentration of $10 \mu \mathrm{g} / \mathrm{ml}$ lipid$100 \mathrm{nM}$ M1GS RNA. The transfection experiments were carried out by using $100 \mathrm{nM}$ M1GS RNA. At $12 \mathrm{~h}$ post-transfection, cells were serum starved for $12 \mathrm{~h}$ and then infected (or mock-infected) by HCV (strain JFH1) at a multiplicity of infection (MOI) of 1-5 in an inoculum of $1.5 \mathrm{ml}$ DMEM supplemented with 1\% FCS. After $2 \mathrm{~h}$ of exposure to the virus at $37^{\circ} \mathrm{C}$, the inoculum was replaced with DMEM supplemented with $10 \%$ FCS.

\section{Inhibition assay of viral gene expression by M1GS ribozyme}

To measure the inhibition of viral gene expression by M1GS ribozyme, viral RNA and core protein were detected by Northern blotting and Western blotting, respectively. Cells were harvested at $48 \mathrm{~h}$ post-infection. For Northern blotting, RNA extract was prepared as described previously [22]. The RNA fractions were separated in $1 \%$ agarose gels containing formaldehyde, transferred to a nitrocellulose membrane, hybridized with ${ }^{32} \mathrm{P}$-labeled DNA probes that contained the cDNA sequences of $\mathrm{HCV}$ core coding region, M1 RNA gene or human $\beta$-actin gene, and analyzed with a Typhoon 9200 PhosphorImager. The radiolabeled DNA probes were used to detect HCV RNA (9.6 kb), M1GS RNAs ( 0.48 kb) and human $\beta$-actin mRNA, respectively. For Western blotting, the cells were harvested and washed twice with phosphate-buffered saline (PBS), and lysed in disruption buffer consisting of $0.05 \mathrm{M}$ Tris ( $\mathrm{pH} 7.0$ ), 8.5\% (w/w) sucrose, $5 \%(\mathrm{w} / \mathrm{w}) \beta$-mercaptoethanol and $2 \%(\mathrm{w} / \mathrm{w})$ sodium 
dodecyl sulfate. The protein samples were boiled for $5 \mathrm{~min}$ before electrophoretic separation on $9 \%(\mathrm{w} / \mathrm{w})$ SDS-polyacrylamide denaturing gels cross-linked with $\mathrm{N}$, N'-methylenebisacylamide. The separated polypeptides were transferred electrically to PVDF membranes and reacted to the antibodies against $\mathrm{HCV}$ core protein and human GAPDH. The membranes were subsequently stained with a chemiluminescent substrate using a Western chemiluminescent substrate kit (Bestbio Company, Shanghai) and quantitated with a Typhoon 9200 phosphorImager. Quantitation was performed in the linear range of protein detection.

\section{Inhibition assays of viral growth by M1GS ribozyme}

Huh7.5.1 cells $\left(n=5 \times 10^{5}\right)$ were infected with $\mathrm{HCV}$ at an MOI of 1, and harvested at 4, 24, 36, 72 and $96 \mathrm{~h}$ post-infection. The HCV RNA copies in the medium were respectively determined by fluorescence quantitative PCR, which was performed in a LightCycler 480 thermal cycler (Roche) under the following conditions: heat activation of the polymerase for $5 \mathrm{~min}$ at $95^{\circ} \mathrm{C}$, followed by 40 cycles of $95^{\circ} \mathrm{C}$ for $15 \mathrm{sec}, 55^{\circ} \mathrm{C}$ for $15 \mathrm{sec}$ and $72^{\circ} \mathrm{C}$ for $20 \mathrm{sec}$. The final melting curve was measured from $50^{\circ} \mathrm{C}$ to $95^{\circ} \mathrm{C}$. The primers for HCV RNA were 5' -CGTTCTTGCGTCCTTCATCT-3' (forward) and 5'CACAAAGTAGGGCTTGGTCAT-3' (reverse). The primers for $\beta$-actin (internal standard) were $5^{\prime}$-TCGTCC ACCGCAAATGCTTCTAG-3' (forward) and 5' -ACTGC TGTCACCTTCACCGTTCC-3' (reverse).

\section{Results}

\section{Construction of M1GS ribozymes}

The 5' UTR of HCV genomic RNA consists of 341 nucleotides and folds to six secondary structure domains termed SLI-VI. SLII, III and IV form an IRES that facilitates the translation of capless HCV RNA [23]. IRES is present in a highly organized conformation and associated with proteins inside cells. In order to achieve efficient targeting, it is pivotal to choose a targeting region which is accessible to binding of ribozymes. Therefore, DNAMAN (v. 6) and RNA structure (v. 4.5) softwares were used to analyze the sequence and secondary structure of HCV 5' UTR to search for sequences with recognition and cleavage features of M1GS ribozyme as characterized previously, including requirement for a guanosine and a pyrimidine to be the $3^{\prime}$ and $5^{\prime}$ nucleotides adjacent to the site of cleavage, respectively [24]. It was found that three sites were critical for the cleavage by M1GS ribozyme, and a position 67 nucleotides downstream from the first nucleotide of HCV genome was chosen as the cleavage site for M1GS RNA because this site appears to be one of the regions most accessible to HCV RNA in the 5' UTR. Moreover, the flanking sequence of the site also exhibited several features needed to interact with an M1GS ribozyme to achieve efficient cleavage (Figure 2).

According to the flanking sequence of the chosen site, two M1GS ribozymes, i.e. M1GS-HCV/C 67 and M1GS$\mathrm{HCV} / \mathrm{C}_{67}{ }^{*}$, were constructed by covalently linking the 3 ' termini of M1 RNA with a 13-nucleotide GS that was complementary to the targeted RNA sequence. As shown in Figure 3, M1GS-HCV/C 67 contained a bridge sequence between GS and M1 RNA, whereas M1GS$\mathrm{HCV} / \mathrm{C}_{67} *$ ribozyme had no bridge sequence - the same GS was directly linked to the 3' termini of M1 RNA without a linker. Then the DNA fragments containing M1GS genes were inserted in EcoR I/Hind III sites of pUC19, and the two recombinant plasmids pM1GS$\mathrm{HCV} / \mathrm{C}_{67}$ and $\mathrm{pM} 1 \mathrm{GS}-\mathrm{HCV} / \mathrm{C}_{67}{ }^{*}$ thus obtained were determined by PCR and double endonuclease digestion, and further verified by sequencing (data no shown). To

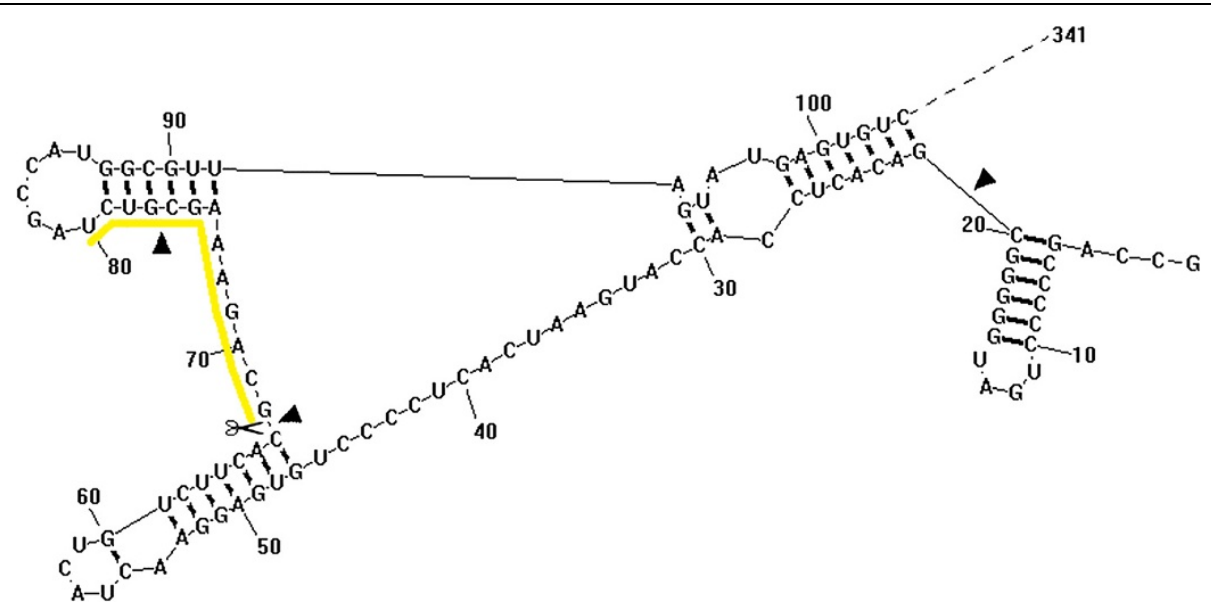

Figure 2 Secondary structure of a portion of HCV 5' UTR predicted by the RNA Structure software. The three sites indicated by triangular arrows were potential cleavage sites of M1GS ribozyme. The site indicated by scissors was an optimal cleavage site, with the sequence marked by a yellow line capable of forming a long single-strand structure and facilitating complementary binding with the GS sequence of M1GS ribozyme. 


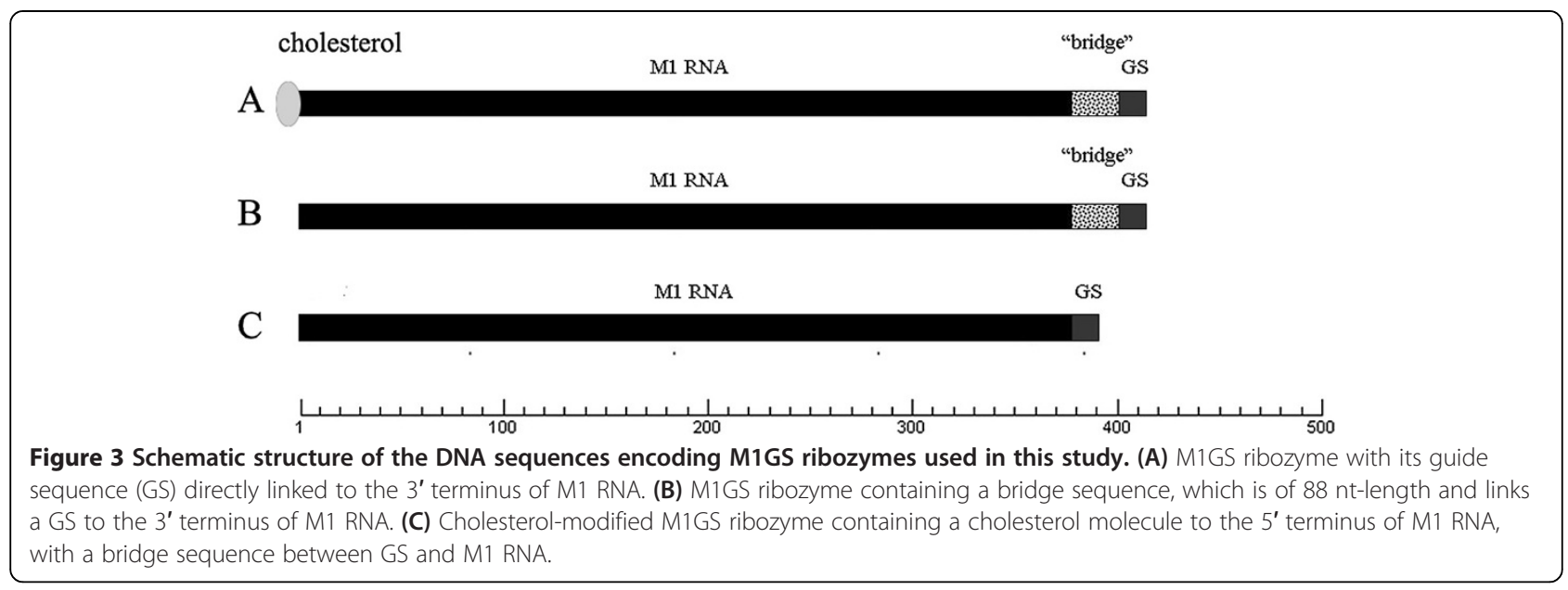

obtain M1GS RNAs, pM1GS-HCV/C 67 and pM1GS$\mathrm{HCV} / \mathrm{C}_{67} 7^{*}$ were first Hind III-linearized and then synthesized in vitro by T7 RNA polymerase. The transcripts of $\mathrm{M} 1 \mathrm{GS}-\mathrm{HCV} / \mathrm{C}_{67}$ and $\mathrm{M} 1 \mathrm{GS}-\mathrm{HCV} / \mathrm{C}_{67} *$ ribozymes were confirmed to be $481 \mathrm{nt}$ and $393 \mathrm{nt}$, respectively (Figure 4).

\section{In vitro cleavage activity of M1GS ribozymes}

$\mathrm{S}_{1-584}$, a substrate containing the front 584 nucleotides of HCV genomic RNA, was used to test the cleavage activity of M1GS ribozymes (Figure 4 Lanes 8-10). The ribozymes and RNA substrate were synthesized in vitro and then incubated for ribozyme cleavage assays. No cleavage of $\mathrm{S}_{1-584}$ was detected in the absence of M1GS RNA (Figure 5 Lane 1), while efficient cleavage of the substrate by M1GS-HCV/C 67 or Chol-M1GS-HCV/C 67 ribozyme yielding products of 67 and 528 nucleotides

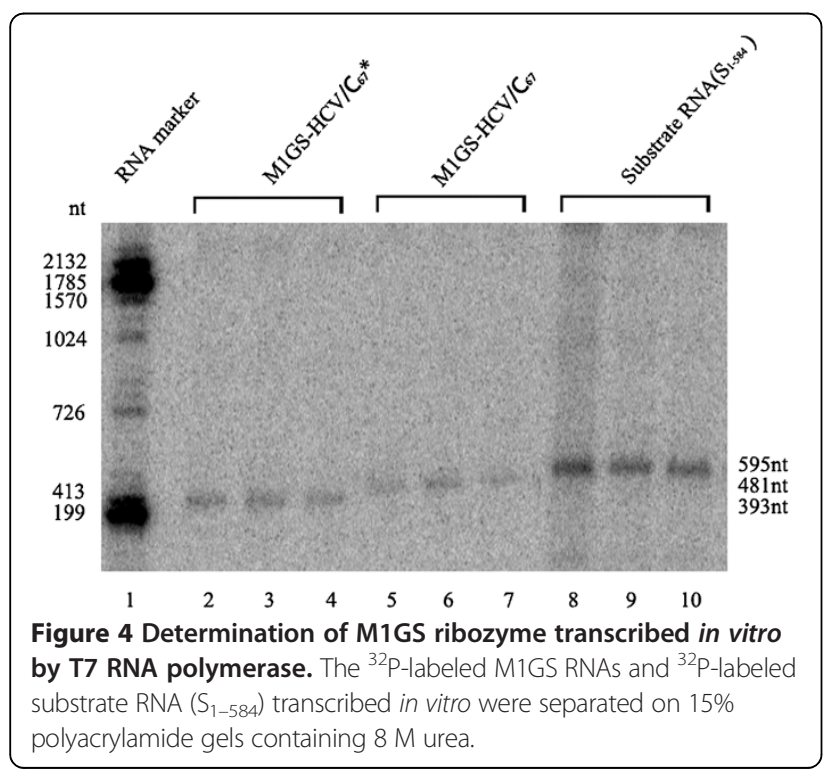

was observed (Figure 5 Lane 2 and 4). These results demonstrate that M1GS-HCV/C 67 was a functional ribozyme and that cholesterol modification did not affect the in vitro cleavage activity of the ribozyme. However, cleavage of the same substrate by M1GS-HCV/C $67^{*}$ ribozyme was barely detected (Figure 5 Lane 3), suggesting M1GS-HCV/C $67^{*}$, which contains the same antisense GS as M1GS-HCV/C 67 but is catalytically

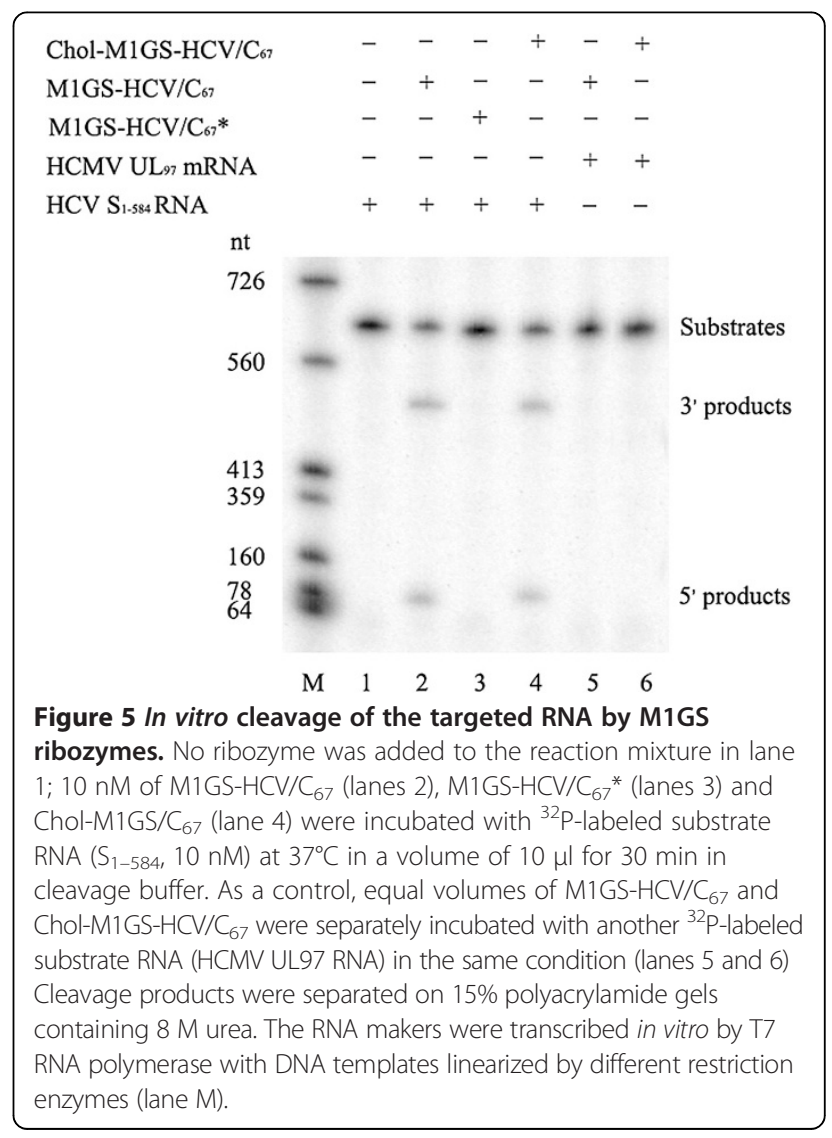


inactive, can be used as a control for antisense effect in cultured cells.

Inhibition of HCV gene expression in M1GS-transfected cells To determine whether M1GS ribozymes inhibit HCV gene expression, Huh7.5.1 cells were first transfected with M1GS RNAs and then infected with JFH1 at a MOI of 5. Total cellular RNAs and proteins were prepared from the infected cells at $48 \mathrm{~h}$ post-infection. The levels of HCV RNA were determined by Northern analysis, with the M1GS RNA and $\beta$ actin mRNA as internal controls (Figure 6B and $\mathrm{C}$ ). Obvious reduction of the HCV RNA levels was observed in cells transfected with M1GS-HCV/C 67 or cholesterol-conjugated M1GS$\mathrm{HCV} / \mathrm{C}_{67}$ (Figure $6 \mathrm{~A}$, Lanes 4 and 5), while almost no reduction was found in cells transfected with M1GS$\mathrm{HCV} / \mathrm{C}_{67} *$ (Figure $6 \mathrm{~A}$, Lane 3). Furthermore, more than $85 \%$ reduction of $\mathrm{HCV}$ core protein level in cells transfected with M1GS-HCV/C 67 or Chol-M1GS-HCV/C 67 was also revealed by Western blotting with GAPDH as an internal control (Figure 7, Lane 3 and 4), while no obvious reduction was found in cells transfected with M1GS$\mathrm{HCV} / \mathrm{C}_{67}{ }^{*}$ (Figure 7, Lane 5).

\section{Inhibition of viral growth by M1GS ribozyme}

To test whether $\mathrm{HCV}$ growth is inhibited by ribozyme transfection, cells were infected by JFH1 at an MOI of 1 and harvested at 4, 24, 36, 72 and $96 \mathrm{~h}$ post-infection. Viral RNA copies in the culture medium at the indicated times were determined. As shown in Figure 8, no significant reduction was found in the cell cultures transfected with M1GS-HCV $/ \mathrm{C}_{67} *$, but $>1000$-fold reduction in viral yield was observed in supernatant of cultured cells transfected with M1GS-HCV/C 67 or Chol-M1GS-HCV/C 67 after $24 \mathrm{~h}$ of infection. These results suggest that M1GSmediated targeting of viral RNA effectively inhibits $\mathrm{HCV}$ growth and cholesterol modification on M1GS ribozyme does not reduce its antiviral activity.

\section{Discussion}

RNase $\mathrm{P}$ is an essential ribonucleoprotein complex found in all three domains of life. The RNase P holoenzyme is composed of an RNA subunit and one or more protein subunits. The RNA component is the catalytic moiety of RNase P across all phylogenetic domains, and is responsible for the maturation of $5^{\prime}$ termini of all pretRNAs, which account for about $2 \%$ of total cellular RNA [25]. A unique feature of RNase $P$ is its recognition of substrate structures and thus is able to hydrolyze different natural substrates [26]. This is of great advantage because recognition of structures rather than sequences may help the fight against variable viruses as single or even double mutations in the target sequence may well be tolerated [27]. It is well known that $\mathrm{HCV}$ is highly variable, and it has been proved that HCV genome cannot be defined by a single sequence but by a population of closely related variant sequences [28]. In consideration of the "quasispecies" nature of HCV genome [29], the RNase P-based M1GS ribozyme is a promising antisense technique in HCV therapeutic studies.

HCV 5' UTR is the most conserved locus within its genome and thus efforts related to HCV RNA therapeutics have been focused on this locus [30]. Nevertheless, this region has a highly stable RNA structure and is modulated by miRNAs and RNA-binding proteins, which limits the number of accessible sites for ribozyme targeting [31]. Therefore, it is important to select the target regions from the 5' UTR of HCV RNA that are accessible to M1GS binding. In this study, we first analyzed the sequence of HCV $5^{\prime}$ UTR and found that three sites, i.e. $C^{20}-G^{21}, C^{67}-G^{68}$ and $U^{76}-G^{77}$, met the general features for M1GS cleavage activities [32]. All the three

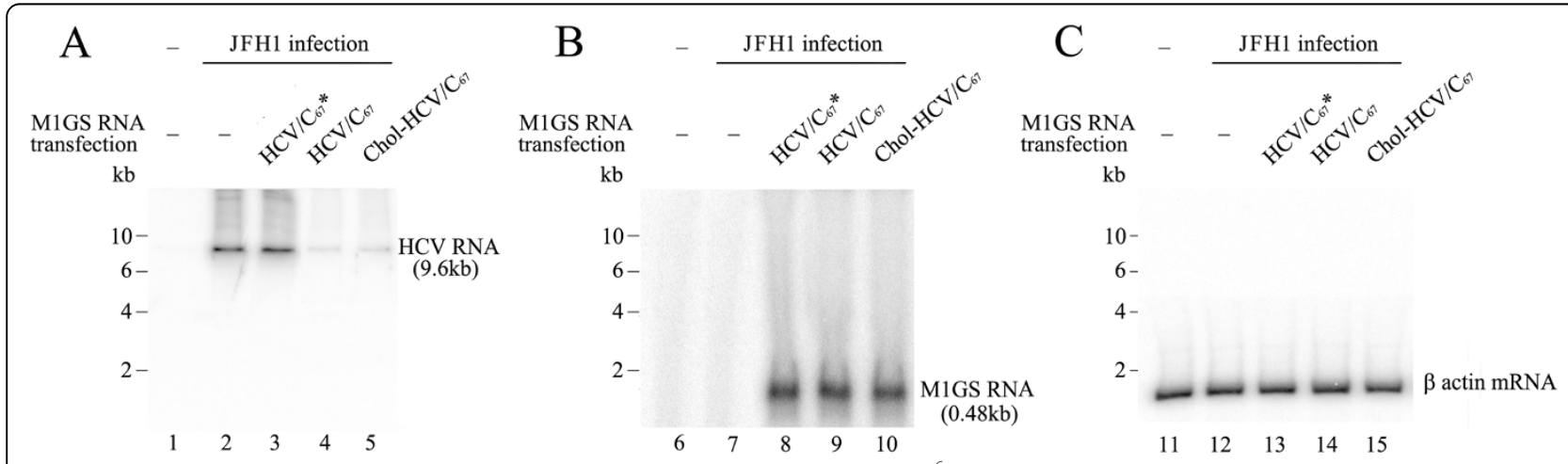

Figure 6 Levels of HCV RNA as determined by Northern analysis. Cells $\left(n=1 \times 10^{6}\right)$ were either mock-infected (lanes 1, 6 and 11$)$ or infected with JFH1 $(\mathrm{MOI}=5)$ and harvested at $48 \mathrm{~h}$ after infection. Northern analysis was carried out with RNA isolated from Huh7.5.1 cells transfected with M1GS-HCV/C $67^{*}$ (lanes 3, 8 and 13), M1GS-HCV/C 67 (lanes 4, 9 and 14), and Chol-M1GS-HCV/C 67 (lanes 5, 10 and 15). Equal amount of each RNA sample was separated on agarose gels containing formaldehyde, transferred to a nitrocellulose membrane, and hybridized to a ${ }^{32} \mathrm{P}$-radiolabeled probe containing the cDNA sequences of HCV core coding region (A), M1 RNA gene (B), and human $\beta$-actin gene (C), respectively. 


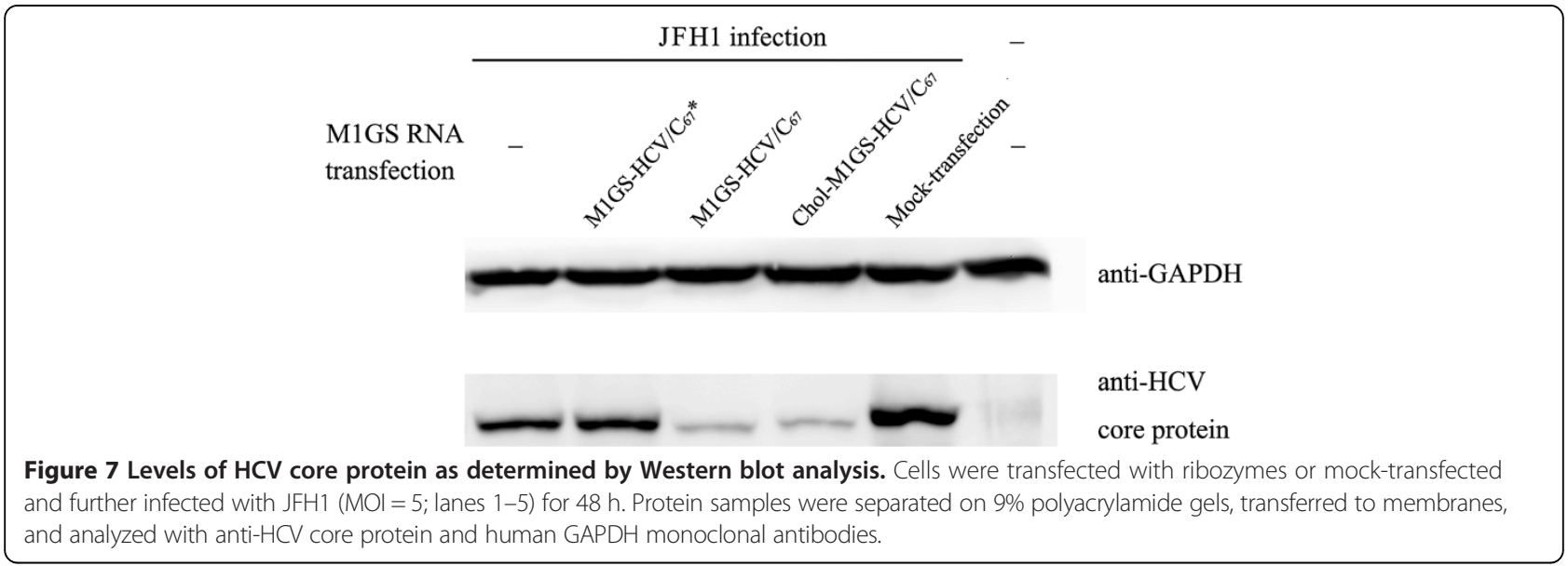

sites were located in the front one third of HCV 5' UTR. Further analysis on the secondary structure of this portion with RNA structure software revealed that the 3' flanking sequence of the site $C^{67}-G^{68}$ formed a long single-strand region but the flanking sequence of $\mathrm{C}^{20}-\mathrm{G}^{21}$ or $\mathrm{U}^{76}-\mathrm{G}^{77}$ folded into a stable stem-loop structure (Figure 2), while the effect of long range annealing would make relevant regions less accessible for targeting [33,34]. Therefore, the region near $C^{67}-G^{68}$ may be more accessible for ribozyme binding.

Based on the above putative site $\left(\mathrm{C}^{67}-\mathrm{G}^{68}\right)$, a custom guide sequence was designed, which was covalently linked to the 3 ' termini of M1 RNA through an 88 ntlong bridge sequence, and a new targeting enzyme (i.e. M1GS-HCV/C 67 ) for the 5' UTR of HCV RNA was successfully constructed. In consideration of the influence of bridge sequence on the cleavage activities of M1GS as previously reported [35], a M1GS without a bridge, i.e. M1GS-HCV $/ \mathrm{C}_{67^{*}}$, was also constructed as a control. As shown in Figures 7 and 8, about 85\% reduction of the expression level of HCV core protein and $>1000$-fold reduction of viral growth were observed in supernatant of cultured cells transfected with M1GS-HCV/C 67 ribozyme. On the other hand, no obvious reduction of the levels of core gene expression and viral growth was observed in cells transfected with M1GS-HCV/C $67^{*}$. Because M1GS-HCV/ $\mathrm{C}_{67} *$ contained an identical guide sequence with M1GS-HCV/C 67 and thus had a similar binding affinity to target sequence. Therefore, the overall inhibition of viral gene expression and growth by M1GS-HCV/C 67 was mainly due to the targeted cleavage by the ribozyme, as opposed to antisense or other nonspecific effects of the guide sequence.

It has been reported that cholesterol-modified siRNAs can be easily bound to human serum albumin, and thus cholesterol modification has the potential to improve in vivo pharmacokinetic properties of RNA therapeutics and broaden their tissue biodistribution [36]. Therefore, M1GS RNA was modified in this study with cholesterol on the $5^{\prime}$ terminus of M1 RNA within the ribozyme, and the cholesterol-conjugated M1GS ribozyme (i.e. Chol-M1GS-HCV/C 67 ) did not lose its cleavage activity

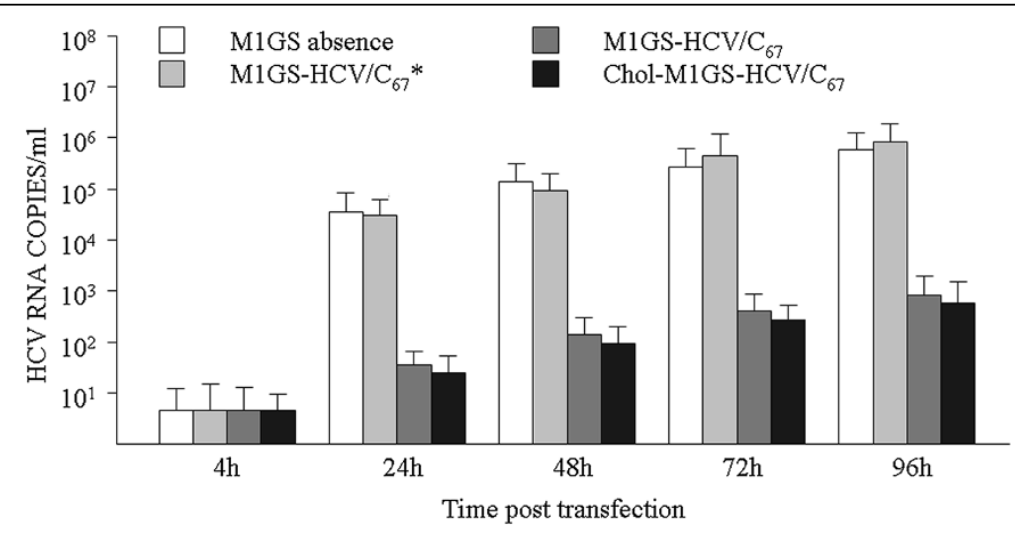

Figure 8 Viral titers in supernatant of cultured cells that transfected with M1GS ribozyme. Huh7.5.1 cells were infected with JFH1 at a MOI of 1. The culture supernatants were then harvested at the indicated times. Quantitation of HCV titer was determined from viral RNA copies by real-time PCR method. Data shown were the means from triplicate experiments. 
in vitro (Figure 5 Lane 4). Furthermore, similar to the unconjugated M1GS RNAs, Chol-M1GS-HCV/C 67 was able not only to efficiently inhibit HCV gene expression in transiently transfected Huh7.5.1 cells (Figure 6 Lane 5 and Figure 7 Lane 4) but also to significantly reduce viral titers in the culture supernatant (Figure 8). Together, our data demonstrate the successful use of an M1GS ribozyme in the inhibition of HCV multiplication and provide an insight into the potential of M1GS-base therapeutics against $\mathrm{HCV}$ infection.

\section{Abbreviations \\ HCV: Hepatitis C virus; GS: Guide sequences; UTR: Un-translated region; MOI: Multiplicity of infection.}

\section{Competing interests}

The authors declare that they have no competing interests.

\section{Authors' contributions}

XLM designed the study, carried out the main experiments, analyzed results and drafted the manuscript. XFL initially conceived of the study. XJM analyzed the data and helped to edit the manuscript. ZWH and CCZ participated in gene cloning and sequence alignment. JGW helped for establishing the HCV culture system. WJZ and GL participated in the design of the study and the critical view of manuscript writing, they were the co-corresponding authors. All authors read and approved the final manuscript.

\section{Acknowledgments}

This work was supported by the Open Research Fund Program of the State Key Laboratory of Virology of China (Grant No. 2012008), the Natural Science Foundation of Guangdong Province (Grant No. S2012010009471), the Science and Technology Planning Project of Guangdong Province (Grant No. 2010B060900041) and the China Postdoctoral Science Foundation (Grant No. 2013 M540601).

\section{Author details}

${ }^{1}$ Vaccine Institute, The Third Affiliated Hospital of Sun Yat-sen University, Guangzhou 510630, PR China. ²Department of Microbiology and Immunology, Guangdong Pharmaceutical University, Guangzhou Higher Education Mega Center, Guangzhou 510006, PR China. ${ }^{3}$ Department of Anaesthesia, General Intensive Care and Pain Management, Medical University of Vienna, Vienna A-1090, Austria. ${ }^{4}$ State Key Laboratory of Virology, Wuhan University, Wuhan 430072, PR China.

Received: 29 January 2014 Accepted: 30 April 2014

Published: 13 May 2014

\section{References}

1. Hengli T, Henry G: Cellular and molecular biology of HCV infection and hepatitis. Clin Sci 2009, 117:49-65.

2. Piñeiro D, Martinez-Salas E: RNA structural elements of hepatitis $C$ virus controlling viral RNA translation and the implications for viral pathogenesis. Viruses 2012, 4:2233-2250.

3. Ploss A, Dubuisson J: New advances in the molecular biology of hepatitis $C$ virus infection: towards the identification of new treatment targets. Gut 2012, 61:i25-i35.

4. Imhof I, Simmonds P: Genotype differences in susceptibility and resistance development of hepatitis $C$ virus to protease inhibitors telaprevir (VX-950) and danoprevir (ITMN-191). Hepatol 2011, 53:1090-1099

5. Ellis JC, Brown JW: The RNase P family. RNA Biol 2009, 6:362-369.

6. Guerrier-Takada C, Gardiner K, Marsh T, Pace N, Altman S: The RNA moiety of ribonuclease $\mathrm{P}$ is the catalytic subunit of the enzyme. Cell 1983, 35:849-857.

7. Liu F, Altman S: Inhibition of viral gene expression by the catalytic RNA subunit of RNase P from Escherichia coli. Genes Dev 1995, 9:471-480.

8. Bai Y, Sunkara N, Liu F: Targeting mRNAs by engineered sequencespecific RNase P ribozymes. Methods Mol Biol 2012, 848:357-368.
9. Raj SM, Liu F: Engineering of RNase P ribozyme for gene-targeting applications. Gene 2003, 313:59-69.

10. Plehn-Dujowich D, Altman S: Effective inhibition of influenza virus production in cultured cells by external guide sequences and ribonuclease P. Proc Natl Acad Sci U S A 1998, 95:7327-7332.

11. Trang P, Lee J, Kilani AF, Kim J, Liu F: Effective inhibition of herpes simplex virus 1 gene expression and growth by engineered RNase $P$ ribozyme. Nucleic Acids Res 2001, 29:5071-5078.

12. Kim K, Trang $P$, Umamoto $S$, Hai R, Liu F: RNase $P$ ribozyme inhibits cytomegalovirus replication by blocking the expression of viral capsid proteins. Nucleic Acids Res 2004, 32:3427-3434

13. Bai Y, Rider PJ, Liu F: Catalytic M1GS RNA as an antiviral agent in animals. Methods Mol Biol 2010, 629:339-353.

14. Kim K, Umamoto S, Trang P, Hai R, Liu F: Intracellular expression of engineered RNase $P$ ribozymes effectively blocks gene expression and replication of human cytomegalovirus. RNA 2004 $10: 438-447$

15. Zeng W, Chen YC, Bai Y, Trang P, Vu GP, Lu S, Wu J, Liu F: Effective inhibition of human immunodeficiency virus 1 replication by engineered RNase P ribozyme. PLoS One 2012, 7:e51855. doi: 10.1371.

16. Trang P, Kim K, Liu F: Developing RNase $P$ ribozymes for gene-targeting and antiviral therapy. Cell Microbiol 2004, 6:499-508.

17. Nadal A, Martell M, Lytle JR, Lyons AJ, Robertson HD, Cabot B, Esteban Jl, Esteban R, Guardia J, Gómez J: Specific cleavage of hepatitis C virus RNA genome by human RNase P. J Biol Chem 2002, 277:30606-30613.

18. Lyons AJ, Robertson HD: Detection of tRNA-like structure through RNase P cleavage of viral internal ribosome entry site RNAs near the AUG start triplet. J Biol Chem 2003, 278:26844-26850.

19. Piron M, Bequiristain N, Nadal A, Martínez-Salas E, Gómez J: Characterizing the function and structural organization of the $5^{\prime}$ tRNA-like motif within the hepatitis $C$ virus quasispecies. Nucleic Acids Res 2005, 33:1487-1502

20. Sabariegos R, Nadal A, Beguiristain N, Piron M, Gómez J: Catalytic RNase P RNA from Synechocystis sp. cleaves the hepatitis $C$ virus RNA near the AUG start codon. FEBS Lett 2004, 577:517-522.

21. Ray PS, Das S: Inhibition of hepatitis $C$ virus IRES-mediated translation by small RNAs analogous to stem-loop structures of the $5^{\prime}$-untranslated region. Nucleic Acids Res 2004, 32:1678-1687.

22. Zhang WJ, Li HJ, Li YQ, He HK, Tang DS, Zhang X, Zhou TH: Construction of an effective M1GS ribozyme targeting HCMV UL97 mRNA segment in vitro. Yi Chuan Xue Bao 2005, 32:1205-1212.

23. Lukavsky PJ: Structure and function of HCV IRES domains. Virus Res 2009, 139:166-171.

24. Frank DN, Pace NR: Ribonuclease P: unity and diversity in a tRNA processing ribozyme. Annu Rev Biochem 1998, 67:153-180.

25. Esakova O, Krasilnikov AS: Of proteins and RNA: the RNase P/MRP family. RNA 2010, 16:1725-1747.

26. Jarrous N, Gopalan V: Archaeal/eukaryal RNase P: subunits, functions and RNA diversification. Nucleic Acids Res 2010, 38:7885-7894.

27. Altman S: RNase $P$ in research and therapy. Biotechnol 1995, 13:327-329.

28. Martell M, Esteban Jl, Quer J, Genesca J, Weiner A, Esteban R, Guardia J, Gómez J: Hepatitis C virus (HCV) circulates as a population of different but closely related genomes: quasispecies nature of HCV genome distribution. J Virol 1992, 66:3225-3229.

29. Domingo E, Gomez J: Quasispecies and its impact on viral hepatitis. Virus Res 2007, 127:131-150.

30. Dasgupta A, Das S, Izumi R, Venkatesan A, Barat B: Targeting internal ribosome entry site (IRES)-mediated translation to block hepatitis $C$ and other RNA viruses. FEMS Microbiol Lett 2004, 234:189-199.

31. Macejack DG, Jensen $K L$, Jamison SF: Inhibition of hepatitis $C$ virus RNA-dependent translation and replication of a chimeric HCV poliovirus using synthetic stabilized ribozymes. Hepatol 2000, 31:769-776.

32. Liu F, Altman S: Requirements for cleavage by a modified RNase $\mathrm{P}$ of a small model substrate. Nucleic Acids Res 1996, 24:2690-2696.

33. Lyons AJ, Lytle JR, Gomez J, Robertson HD: Hepatitis C virus internal ribosome entry site RNA contains a tertiary structural element in a functional domain of stem-loop II. Nucleic Acids Res 2001, 29:2535-2541.

34. Lima WF, Wu HJ, Nichols JG, Sun H, Murray HM, Crooke ST: Binding and cleavage specificities of human argonaute. J Biol Chem 2009, 284:26017-26028 
35. Zhang WJ, Li YQ, Li HJ, Jia XF, Zhang X, Zhou TH: The influence of bridge sequence on the cleavage activities of M1GS ribozyme in vitro. J Guangdong Coll Pharm 2006, 22:527-540.

36. Jurgen S, Akin A, Birgit B, Klaus C, Rainer C, Mary D, Sayda E, Anke G, Philipp H, Jens H, Matthias J, Venkitasamy K, Gary L, Pandey RK, Timothy R, Rajeev KG, Ivanka T, Gang W, Silvio W, David B, Victor K, Stefan L, Muthiah M, Vornlocher HP: Therapeutic silencing of an endogenous gene by systemic administration of modified siRNAs. Nature 2004, 432:173-178.

doi:10.1186/1743-422X-11-86

Cite this article as: Mao et al: Inhibition of hepatitis $C$ virus by an M1GS ribozyme derived from the catalytic RNA subunit of Escherichia coli RNase P. Virology Journal 2014 11:86.

\section{Submit your next manuscript to BioMed Central and take full advantage of:}

- Convenient online submission

- Thorough peer review

- No space constraints or color figure charges

- Immediate publication on acceptance

- Inclusion in PubMed, CAS, Scopus and Google Scholar

- Research which is freely available for redistribution 